\title{
Analisis soal uji kompetensi pada buku paket matematika siswa kurikulum 2013 untuk SMP/MTs kelas VII semester 1 ditinjau dari taksonomi Bloom
}

\section{Ni Nyoman Yulia Paicasari ${ }^{*}$, Ketut Sarjana ${ }^{2}$ Eka Kurniawan ${ }^{2}$, Syahrul Azmi ${ }^{2}$}

${ }^{1}$ Mahasiswa Pendidikan Matematika, FKIP, Universitas Mataram, Mataram

2 Pendidikan Matematika, FKIP, Universitas Mataram, Mataram

yuliapaicasari20@gmail.com

Diterima: 11 Juni 2021; Direvisi: 29 Juni 2021; Dipublikasi: 30 Juni 2021

\begin{abstract}
The purpose of this study was to identify the cognitive level of competency test questions in the mathematics textbook for students of 2013 Curriculum for SMP/MTs grade $7^{\text {th }}$ semester 1 reviewed from Revised Bloom Taxonomy. Therefore, this type of research is descriptive research. The data source in this study is the student mathematics textbook 2013 Curriculum Edition 2017 Revision for SMP / MTs grade VII semester 1 . While the research variable is the cognitive level of each item of competency test in the 2013 Curriculum student mathematics textbook for SMP/MTs grade $7^{\text {th }}$ semester 1 . Data collection was performed by using the documentation and questionnaire methods. The guideline used in the item analysis is the Revised Bloom Taxonomy cognitive level which includes C1-remembering; C2-understand; C3applying; C4-analyze; C5-evaluate; and C6-creating. The results of this study obtained the percentage of $\mathrm{C} 1$ cognitive level of $13.69 \%$; C2 of $23.17 \%$; C3 at $51.57 \%$; C4 of $8.42 \%$; C5 at $1.05 \%$ and $\mathrm{C} 6$ at $2.11 \%$. It can be concluded that the results of the cognitive level of competency test questions in the mathematics textbook for students of Curriculum 2013 for SMP/MTs grade $7^{\text {th }}$ semester 1 are still low and have not met the balance of the difficulty level of the questions.
\end{abstract}

Keywords: Analysis; Competency Test Problem; Revised Bloom Taxonomy

\begin{abstract}
Abstrak
Penelitian ini dilatar belakangi karena rendahnya nilai rata-rata ujian nasional matematika yang mengindikasikan rendahnya kemampuan berfikir tingkat tinggi siswa. Tujuan penelitian ini adalah untuk mengidentifikasi tingkat kognitif soal-soal uji kompetensi pada buku paket matematika siswa Kurikulum 2013 untuk SMP/MTs kelas VII semester 1 ditinjau dari Taksonomi Bloom Revisi. Oleh karena itu, jenis penelitian ini adalah penelitian deskriptif. Sumber data dalam penelitian ini yaitu buku paket matematika siswa Kurikulum 2013 Edisi Revisi 2017 untuk SMP/MTs kelas VII semester 1. Sementara variabel penelitian ini yaitu tingkat kognitif setiap butir soal uji kompetensi dalam buku paket matematika siswa Kurikulum 2013 untuk SMP/MTs kelas VII semester 1. Pengumpulan data yang dilakukan menggunakan metode dokumentasi dan angket. Pedoman yang digunakan pada analisis soal adalah tingkat kognitif Taksonomi Bloom Revisi yang meliputi C1-mengingat; C2-memahami; C3-mengaplikasikan; C4menganalisis; C5-mengevaluasi; dan C6-mencipta. Hasil penelitian ini diperoleh persentase tingkat kognitif C1 sebesar 13,69\%; C2 sebesar 23,17\%; C3 sebesar 51,57\%; C4 sebesar 8,42\%; C5 sebesar 1,05\% dan C6 sebesar 2,11\%. Dapat disimpulkan bahwa tingkat kognitif soal uji kompetensi di dalam buku paket matematika siswa Kurikulum 2013 untuk SMP/MTs kelas VII semester 1 edisi revisi 2017 masih tergolong rendah dan belum memenuhi keseimbangan tingkat kesukaran soal.
\end{abstract}

Kata Kunci: Analisis; Soal Uji Kompetensi; Taksonomi Bloom Revisi 


\section{PENDAHULUAN}

Dalam impelementasi kurikulum 2013, pemerintah telah menyediakan sumber belajar wajib yaitu berupa buku paket siswa (Kemendikbud, 2017). Terkait pembelajaran matematika, siswa menggunakan buku paket matematika siswa Kurikulum 2013 sebagai acuannya. Buku paket matematika siswa Kurikulum 2013 dilengkapi dengan soal-soal latihan yang dirancang untuk dapat mengukur kemampuan berfikir siswa, seperti soal uji kompetensi (Giani, 2015). Soal uji kompetensi terdapat disetiap akhir pokok bahasan tertentu di dalam buku paket matematika siswa Kurikulum 2013.

Soal uji kompetensi merupakan salah satu alat ukur yang digunakan untuk mendeteksi kemampuan siswa (Sałidah, 2019). Salah satunya adalah kemampuan berfikir tingkat tinggi siswa. Kemampuan berfikir tingkat tinggi sangat penting karena terdapat dalam beberapa poin standar kompetensi lulusan sekolah menengah (Susanti dkk, 2015). Untuk mencapai kemampuan berfikir tingkat tinggi dalam pembelajaran matematika, siswa perlu dibiasakan menyelsaikan soal-soal yang membutuhkan pemikiran untuk C4-menganalisis, C5-mengevaluasi, dan C6-mencipta.

Pemberian soal hendaknya secara hierarkis dari tingkat kemampuan rendah sampai tingkat kemampuan tinggi (Nasrulloh, 2011). Sehingga perlu diadakan pengklasifikasian tingkat kognitif soal yang dapat memudahkan siswa dalam mengerjakan soal secara bertahap dari yang mudah sampai yang tersulit. Klasifikasi tingkat kognitif soal yang paling dikenal dalam dunia pendidikan matematika ialah Taksonomi Bloom (Tim Pusat Penilaian Pendidikan, 2019). Menurut Taksonomi Bloom yang telah direvisi (Anderson dkk, 2015) tingkat kognitif terbagi menjadi kemampuan berfikir tingkat rendah (Low Order Thinking Skills) meliputi tingkat kognitif mengingat (C1), memahami (C2), dan menerapkan (C3), sedangkan kema mpuan berfikir tingkat tinggi (High Order Thinking Skills) meliputi tingkat kognitif menganalisis (C4), mengevaluasi (C5), dan mencipta (C6). Di sisi lain, penggunaan kata kerja operasional yang disusun dalam Taksonomi Bloom Revisi digunaka untuk memudahkan dalam mengklasifikasi soal secara hierarkis.

Selain itu, Kualitas soal dapat dilihat dari adanya keseimbangan dari tingkat kesukaran soal (Maemunah, 2019)). Keseimbangan yang dimaksudkan adalah perbandingan antara soal mudah-sedang-sulit yang bisa digambarkan 3:4:3 dimana yang soal mudah tergolong tingkat kognitif (C1-C2), soal sedang (C3-C4), dan soal sulit ( C5-C6) secara proporsional (Sudjana, 1992). Berdasarkan perbandingan tersebut, persentase soal untuk masing-masing tingkat kognitif taksonomi Bloom dirumuskan sebagai berikut, 30\% untuk $\mathrm{C} 1$ dan $\mathrm{C} 2,40 \%$ untuk $\mathrm{C} 3$ dan $\mathrm{C} 4,30 \%$ untuk C5 dan C6.

Oleh karena itu, penelitian analisis tingkat kognitif soal pada buku paket matematika siswa perlu dilakukan, salah satunya buku paket matematika siswa kelas VII Semester 1 untuk SMP/MTs. Penelitian ini dilakukan untuk mengidentifikasi tingkat kognitif soal-soal uji kompetensi pada buku paket matematika siswa Kurikulum 2013 untuk 
SMP/MTs kelas VII semester 1 ditinjau dari Taksonomi Bloom Revisi. Selain itu, penelitian ini juga dilakukan untuk mengidentifikasi persentase ranah $\mathrm{C} 4$ - C6 melengkapi soal-soal uji kompetensi pada buku paket matematika siswa Kurikulum 2013 untuk SMP/MTs kelas VII semester 1.

\section{METODE PENELITIAN}

Jenis penelitian ini adalah penelitian deskriptif. Penelitian deskriptif bertujuan untuk membuat deskripsi atau gambaran mengenai objek atau fenomena yang diteliti (Winarno, 2013). Sumber data dalam penelitian ini yaitu berupa buku paket matematika siswa Kurikulum 2013 Edisi Revisi 2017 untuk SMP/MTs kelas VII semester 1 . Sementara variabel dalam penelitian ini yaitu tingkat kognitif setiap butir soal uji kompetensi dalam buku paket matematika siswa Kurikulum 2013 untuk SMP/MTs kelas VII semester 1.

Adapun langkah-langkah kerja yang yang dilakukan untuk memperoleh data sebagai berikut. 1) Memilih buku paket matematika siswa Kurikulum 2013 untuk SMP/MTs kelas VII semester 1 edisi revisi 2017 yang disusun oleh Abdur Rahman As'ari, dkk. 2) Mengidentifikasi soal uji kompetensi pada buku paket matematika siswa Kurikulum 2013 untuk SMP/MTs kelas VII semester 1 edisi revisi 2017 yang disusun oleh Abdur Rahman As'ari, dkk. 3) Menyusun lembar instrumen berupa lembar klasifikasi soal uji kompetensi yang berisikan pedoman analisis soal uji kompetensi berdasarkan Taksonomi Bloom Revisi. 4) Mengadakan validasi lembar klasifikasi soal uji kompetensi oleh validator yaitu dosen matematika dan guru matematika SMP. 5) Melakukan penilaian terhadap setiap butir soal uji kompetensi dengan menggunakan pedoman lembar instrumen klasifikasi soal uji kompetensi berdasarkan tingkat kognitif Taksonomi Bloom Revisi. Penilaian dilakukan oleh peneliti, guru matematika SMP dan dosen matematika. 6) Mengadakan pemerikasaan keabsahan data dengan melakukan kegiatan triangulasi yaitu diskusi mengenai klasifikasi soal yang sama antara peneliti dengan dosen matematika dan guru matematika SMP. Jika hasil klasifikasi antara peneliti dengan dosen matematika dan guru matematika SMP sesuai maka dilakukan tahap selanjutnya dan jika hasil belum sesuai maka dilakukan diskusi mendalam. 7) Menentukan persentase masing-masing tingkat kognitif Taksonomi Bloom Revisi terhadap soal uji kompetensi. 8) Mengkaji hasil dari semua data yang diperoleh untuk menarik kesimpulan.

Pengambilan data dilakukan dengan menggunakan lembar penilaian yang di dalamnya memuat tabel dengan format kolom kode soal, soal, penyelesaian, jenis tingkatan kognitif Taksonomi Bloom Revisi, dan keterangan. Lembar penilaian ini digunakan untuk menilai atau mengklasifikasi tingkat kognitif setiap butir soal uji kompetensi. Proses penilaian tingkat kognitif soal uji kompetensi melibatkan proses triangulasi penyidik. Menurut Stanley \& Moore (2010) triangulasi penyidik dapat membantu mengurangi kemelencengan dalam pengumpulan data. Data yang diperoleh kemudian diolah dengan menggunakan rumus persentase (Kuswanti dkk, 2107). 


$$
P_{C_{i}}=\frac{f_{i}}{N} \times 100 \%
$$

$$
\begin{aligned}
& \text { Keterangan: } \\
& P_{C_{i}}=\text { persentase pertanyaan tingkat kognitif ke- } i \\
& f_{i}=\text { banyaknya pertanyaan sesuai tingkat kognitif ke- } i \\
& N=\text { jumlah seluruh pertanyaan yang dianalisis } \\
& i \quad=1,2,3,4,5,6
\end{aligned}
$$

\section{HASIL DAN PEMBAHASAN}

\subsection{Hasil Analisis Validasi Instrumen Klasifikasi Soal Uji Kompetensi}

Hasil validasi instrumen klasifikasi tingkat kognitif soal uji kompetensi didapat nilai rerata total $V_{a}=4,11$, maka hasil validasi instrumen klasifikasi soal uji kompetensi berdasarkan tingkat kognitif Taksonomi Bloom Revisi termasuk ke dalam kategori valid. Pada kategori valid, tidak perlu dilakukan validasi kembali, namun hanya dilakukan revisi mengenai isi dan tata bahasa sesuai dengan saran revisi yang diberikan oleh validator ahli.

\subsection{Hasil Analisis Tingkat Kognitif Soal Uji Kompetensi Pada Buku Paket Matematika Siswa Kurikulum 2013 Untuk SMP/MTs Kelas VII Semester 1 Edisi Revisi 2017}

Hasil analisis setelah dilakukan teknik pemeriksaan keabsahan data untuk keseluruhan soal uji kompetensi pada buku paket matematika siswa Kurikulum 2013 untuk SMP/MTs kelas VII semester 1 edisi revisi 2017 berdasarkan 6 tingkat kognitif Taksonomi Bloom Revisi dapat dilihat pada Tabel 1 berikut.

Tabel 1. Rekapitulasi Hasil Penilaian Keseluruhan Soal Uji Kompetensi Pada Buku Paket Matematika Siswa Kurikulum 2013 Untuk SMP/Mts Kelas VII Semester 1 Edisi Revisi 2017

\begin{tabular}{cccccccc}
\hline \multirow{2}{*}{ BAB } & \multicolumn{6}{c}{ TINGKAT KOGNITIF (\%) } & \multirow{2}{*}{ TOTAL (\%) } \\
\cline { 2 - 7 } & C1 & C2 & C3 & C4 & C5 & C6 & \\
\hline I & 6.32 & 6.32 & 5.26 & 1.05 & 0.00 & 0.00 & 18.95 \\
II & 1.05 & 8.42 & 4.21 & 3.16 & 0.00 & 0.00 & 16.48 \\
III & 6.32 & 5.26 & 16.84 & 3.16 & 0.00 & 0.00 & 31.22 \\
IV & 0.00 & 3.16 & 25.26 & 1.05 & 1.05 & 2.11 & 32.63 \\
Jumlah & 13.69 & 23.16 & 51.57 & 8.42 & 1.05 & 2.11 & \\
$\begin{array}{c}\text { Persentase } \\
\text { Jumlah }\end{array}$ & & & & & & & 100.00 \\
$\begin{array}{c}\text { Persentase (C1- } \\
\text { C2, C3-C4, C5- }\end{array}$ & 36.85 & & 59.99 & & 3.16 & \\
C6) & & & & & & & \\
\hline
\end{tabular}




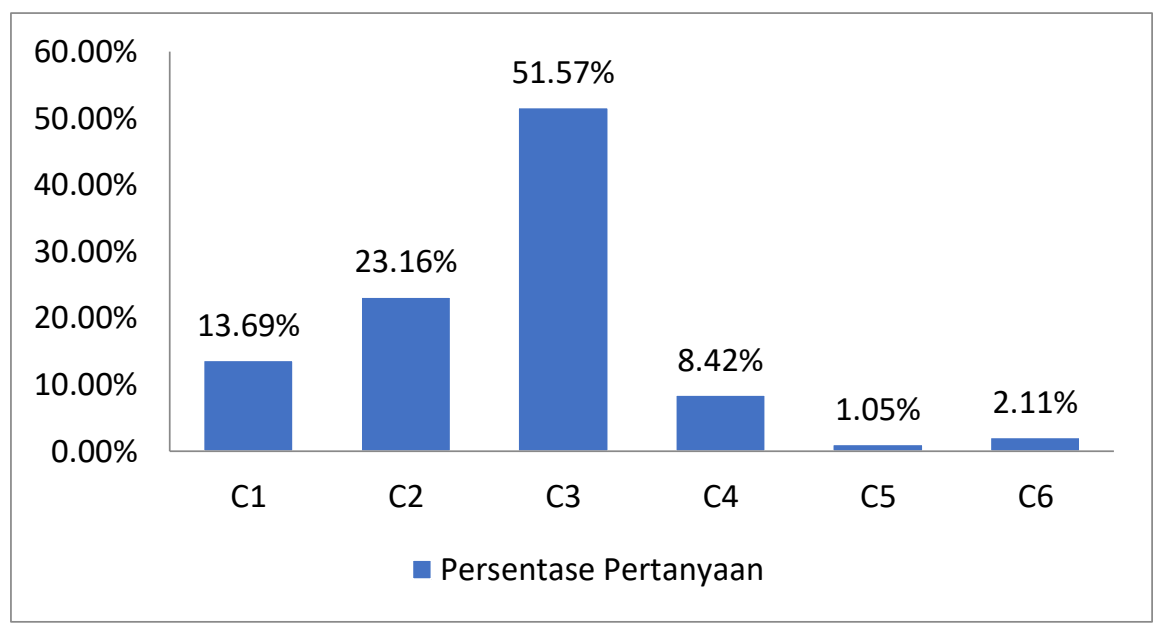

Gambar 1. Persentase keseluruhan tingkat kognitif soal uji kompetensi

\subsection{Pembahasan}

Berdasarkan Gambar 1 di atas, dari keseluruhan soal uji kompetensi pada buku paket matematika siswa Kurikulum 2013 untuk SMP/MTs kelas VII semester 1 edisi revisi 2017 diperoleh persentase tingkat kognitif C1 sebesar 13,69\%; C2 sebesar 23,16\%; C3 sebesar 51,57\%; C4 sebesar 8,42\%; C5 sebesar 1,05\% dan C6 sebesar 2,11\%. Selain itu, pada Gambar 1 juga terlihat bahwa soal uji kompetensi juga didominasi oleh tingkat kognitif $\mathrm{C} 3$.

Dari tingkat kognitif C3 tersebut, siswa diharapkan dapat mengoperasikan dan mengkalkulasikan suatu prosedur atau langkah-langkah penyelesaian dengan keterampilan atau algoritma yang dilalui dengan urutan tetap serta dapat melakukan modifikasi prosedur dalam penyelesaiannya, karena soal-soal C3 disajikan dalam bentuk soal cerita yang biasanya mengaitkan materi pembelajaran dengan masalah dalam kehidupan sehari-hari. Selain itu, salah satu kunci dalam mempelajari matematika adalah dengan banyak berlatih soal-soal (Hasibuan, 2015).

Dari Gambar 1, menunjukkan ketidakseimbangan pertanyaan uji kompetensi pada buku paket matematika siswa Kurikulum 2013 kelas VII semester 1 edisi revisi 2017, karena lebih dari setangah pertanyaan termasuk ke dalam tingkat kognitif C3. Namun, secara keseluruhan tingkat kognitif soal uji kompetensi di dalam buku paket matematika siswa Kurikulum 2013 kelas VII semester 1 edisi revisi 2017 sudah dapat dikatakan baik karena mencakup pertanyaan mudah (C1-C2), sedang (C3-C4), dan sulit (C5-C6).

Hasil penelitian ini sejalan dengan hasil penelitian yang dilakukan oleh Kuswanti dkk (2017) bahwa soal-soal di dalam buku paket matematika siswa Kurikulum 2013 kelas VII semester 1 (edisi revisi 2014) di dominasi oleh domain penerapan. Adanya proporsi soal-soal yang tidak merata menunjukkan kelemahan buku teks yang digunakan terutama dalam mendorong siswa untuk berpikir kritis, kreatif, dan analitis yang 
merupakan aspek tingkatan berpikir tingkat tinggi (High Order Thinking) (Masduki $\mathrm{dkk}, 2013)$.

Tingkat kognitif erat hubungannya dengan kualitas suatu soal. Kualitas soal dapat dilihat dari keseimbangan tingkat kesulitan soal. Menurut Anderson dkk (2015) semakin tinggi tingkat kognitif soal maka semakin tinggi pula kualitas soal tersebut. Pada dasarnya soal yang diberikan kepada siswa semestinya mencakup semua tingkatan kognitif Taksonomi Bloom Revisi dari tingkat kognitif rendah C1, C2, C3 sampai tingkat kognitif tinggi C4, C5, dan C6. Karena setiap soal yang dikerjakan oleh siswa dapat menuntun kemampuan berfikir siswa. Soal dengan tingkat kognitif yang runtun dapat menghubungkan pengetahuan lama dengan pengetahuan baru siswa (Imanuddin, 2015). Sehingga siswa dapat meningkatkan kemampuan berfikir tingkat tinggi. Kemampuan berfikir tingkat tinggi sangat diperlukan untuk menyelesaikan permasalahan-permasalahan yang akan dihadapi siswa di kemudian hari.

\section{SIMPULAN}

Berdasarkan hasil penelitian dan pembahasan, dapat diperoleh kesimpulan yaitu dari keseluruhan soal uji kompetensi pada buku paket matematika siswa Kurikulum 2013 untuk SMP/MTs kelas VII semester 1 edisi revisi 2017 yang diterbitkan oleh Kementerian Pendidikan dan Kebudayaan terdiri dari 80 soal yang memuat 95 pertanyaan yang dapat dinilai atau diklasifikasikan. Dari 95 pertanyaan diperoleh persentase tingkat kognitif C1 sebesar 13,69\%; C2 sebesar 23,17\%; C3 sebesar 51,57\%; C4 sebesar 8,42\%; C5 sebesar 1,05\% dan C6 sebesar 2,11\%. Sebaiknya komposisi keseimbangan soal uji kompetensi pada buku paket matematika siswa Kurikulum 2013 untuk SMP/MTs kelas VII semester 1 edisi revisi 2017 memenuhi keseimbangan proposional yaitu soal mudah (C1-C2) 30\% atau 28 pertanyaan, soal sedang (C3-C4) $40 \%$ atau 39 pertanyaan, dan soal sulit (C5-C6) 30\% atau 28 pertanyaan.

\section{REKOMENDASI}

Untuk penelitian selanjutnya diharapkan dapat melajutkan untuk buku paket matematika siswa selanjutnya atau dapat meneliti soal Ayo Berlatih.

\section{REFERENSI}

Anderson, L.W., Krathwohl, D.R., Airasian, P., Cruikshank, K., Mayer, R., Pintrich, P., Raths, J., \& Wittrock, M. (2015). Taxonomy for learning, teaching, and assessing: A revision of Bloom's taxonomy of educational objectives. London: Pearson.

Giani, G., Zulkardi, Z., \& Hiltrimartim, C. (2015). Analisis tingkat kognitif soal-soal buku teks matematika kelas VII berdasarkan taksonomi Bloom. Jurnal Pendidikan Matematika (JPM), 9(2), 78-98. http://dx.doi.org/10.22342/jpm.9.2.2125.78 - 98.

Hasibuan, I. (2015). Hasil belajar siswa pada materi bentuk aljabar di kelas VII SMP Negeri 1 Banda Aceh tahun pelajaran 2013/2014. Jurnal Peluang, 4(1), 5-11.

Imanuddin, T. N. F. (2015). Analisis tingkat kognitif soal apersepsi pada buku siswa matematika SMP/MTs kelas VII kurikulum 2013 berdasarkan taksonomi Bloom. Skripsi. Universitas Negeri Jember. 
Kemendikbud. (2017). Matematika SMP/MTS kelas VII semester 1. Jakarta: Kemendikbud.

Kuswanti, Y., Setiawati, S., \& Lestari, N. D. S. (2017). Analisis soal dalam buku siswa matematika kurikulum 2013 untuk sekolah menengah pertama kelas VII berdasarkan dimensi kognitif trends international mathematics and science study (TIMSS). Jurnal Edukasi (JUKSI). 4(3): 25-29.

Maemunah, S., \& Ramlah, R. (2019). Analisis buku teks siswa SMP kelas VIII pokok bahasan teorema Pythagoras ditinjau dari taksonomi Bloom. Prosiding Sesiomadika, 2(1d).

Masduki, Subandriah, M.R., Irawan, D.Y., \& Prihantoro, A. (2013). Level kognitif soal-soal pada buku teks matematika SMP kelas VII. Yogyakarta: FKIP UMS.

Nasrulloh, A.H. (2011). Analisis tingkat kognitif tes kompetensi pada buku sekolah elektronik (BSE) matematika SMP/MTs kelas IX berdasarkan berdasarkan taksonomi Bloom. Skripsi. Universitas Negeri Jember.

Sa'idah, N., Yuliatianti, H. D., \& Megawati, F. (2019). Analisis instrument tes higher order thinking matematika SMP. Jurnal Pendidikan Matematika, 13(1), 41-54.

Stanley, T., \& Moore, B. (2009). Critical thinking and formative assessment increasing the rigor in your classroom. London: Routledge.

Sudjana, N. (1992). Penilaian hasil proses belajar mengajar. Bandung: PT Remaja Rosdakarya.

Susanti, N. Y., Trapsilasiwi, D., \& Kurniati, D. 2015. Analisis tingkat kognitif uji kompetensi pada buku sekolah elektronik (BSE) matematika SMP/MTs kelas VII kurikulum 2013 berdasarkan taksonomi Bloom. Kreano, Jurnal Matemaika Kreatif-Inovatif, 6(1), 67-75.

Tim Pusat Penilaian Pendidikan. (2019). Panduan penulisan soal HOTS-higher order thinking skills. Jakarta: Pusat Penilaian Pendidikan

Winarno, M. E. (2013). Metodologi penelitian dalam pendidikan jasmani. Malang: UM Press. 